\title{
Composition of braconidae (hymenoptera) fauna in citrus orchards surrounded by Amazonian secondary forest
}

\begin{abstract}
The Braconidae composition of two Citrus orchards surrounded by Amazon rainforest was investigated. To compare the composition of Braconidae in orchards and forest were installed eighteen modified Malaise traps distributed in a gradient that started inside the orchard 80 meters from the edge extending up to 80 meters from the border inside the forest. The composition of Braconidae differed between forest and orchard, abundance in orchard was lower when compared with the forest and the diversity were higher inside forest. Differences found in the composition is associated with factors such as the presence of hosts in the environment. Was found some potential genera like Utetes, and Pholetesor that can be used in biological control of citrus pests.
\end{abstract}

Keywords: Parasitoid, ichneumonoidea, citrus, amazon, biological control
Volume I Issue 5 - 2017

\author{
Garcia de Oliveira B,' de Souza Gadelha S,' \\ Teles BR ${ }^{2}$ \\ 'Postgraduate Program in Entomology, National Institute of \\ Amazonian Research, Brazil \\ ${ }^{2}$ Biodiversity Coordination, National Institute of Amazonian \\ Research, Brazil
}

\begin{abstract}
Correspondence: Bruno Garcia de Oliveira, National Institute of Research of the Amazon, Av. Bem TeVl, 8-406 - Petrópolis, Manaus, Brazil, Tel +55 92-98। I7-7397, Email brunogaoli@gmail.com
\end{abstract}

Received: September 28, 2017 | Published: December 06, 2017

\section{Introduction}

Brazil is the world's largest producer of oranges [Citrus sinensis L. Osbeck (Sapindales, Rutaceae)] in the world, making the Citrus industry one of the most important crop for Brazilian agro economic. In the Amazon region the Citrus industry is growing, with crops concentrated mainly in Manaus, Iranduba, Rio Preto da Eva and Manacapuru the varieties "Pera-Lima" and "Valencia" are planted in about $2.700 \mathrm{ha}^{1}$ and an example of this growth is the production doubled when compared with five years ago. ${ }^{2}$

Braconidae is the second largest family of Hymenoptera, ${ }^{3}$ with about 46 subfamilies and nearly 20,000 valid species in the world. ${ }^{4}$ They are mostly parasitoids of insects, especially larvae of Lepidoptera, Coleoptera and Diptera. ${ }^{5}$ As their hosts are invariably killed during larval development process, these parasitoids play an important ecological role in regulating populations of other insects many of which could be damaging to agrosystems if their numbers were not contained and that is being applied increasingly in programs of biological control. ${ }^{6}$ In South and Southeast region fruit flies are major pest of citrus $^{7-9}$ and they can be controlled by some species of Braconidae such as Doryctobracon areolatus (Szépligeti) and Diachasmimorpha longicaudata (Ashmead). Another example of the importance of Braconidae for citrus is some aphids that are controlled by Lysiphlebus testaceipes (Cresson) but very little is known about the diversity of Braconidae in the Amazon region.Several works on diversity of fruit flies and their parasitoids contributed not in a direct way to the knowledge of Braconidae in the Amazon region ${ }^{10-17}$ Those works lack on information about Braconidae that is more specific about identification and ecology. There is only three works treating Braconidae diversity in more specific way in Amazonian region and they are not associated with crops. Feitosa et al. ${ }^{18}$, Querino et al. ${ }^{19}$ studied the diversity of parasitoids in general and Gadelha et al. ${ }^{20}$ studied the diversity of Braconidae in a secondary forest.Regarding the growth of citrus industry on Amazonas state and the importance of Braconidae for the biological control of citrus pests this work aimed to compare the composition of Braconidae fauna on two
Citrus orchards and in the surrounding secondary forests and provide information about Braconidae taxonomic fauna as a base for future studies on the implementation of biological control in Amazonian Citrus plantations.

\section{Material and methods}

The study was carried out in two Citrus orchards surrounded by secondary forest located near Rio Preto da Eva City in the Amazonas State. The orchards were located between kilometers 80 and 87 of the AM-010 freeway. Both orchards measured approximately 15 hectares planted with $C$. sinensis, variety "Pera", and were surrounded by secondary Amazon forests with similar floristic composition. In the seven years old Citrus Orchard Aprisco Pasárgada (SAP, 2 ${ }^{\circ} 42^{\prime} 24.65^{\prime \prime} \mathrm{S}$, $59^{\circ} 42^{\prime} 52.56^{\prime}$ W), trees were planted with space of $6 \times 7 \mathrm{~m}$ from each other, corresponding to a total density of 238 plants per hectare. In six years old Citrus orchard Santa Terezinha (SST, 2॰40'16.68'S, $\left.59^{\circ} 39^{\prime} 24.24^{\prime \prime} \mathrm{W}\right)$, trees were planted with space of $5 \times 8$ meters from each other, corresponding to a total density of 250 plants per hectare.

The adult parasitoids were collected using a modified Malaise Trap $^{21}$ (Figure 1). The modifications of the trap consisted in the top being a white pyramid with a base of $1 \mathrm{~m}^{2}$ square made of a very fine mesh and a black crossed septum of $2 \mathrm{~m}$ below touching the ground. On top of the trap a glass collector was attached, filled with $700 \mathrm{ml}$ of a solution composed of $70 \%$ alcohol and glycerin in the ratio of 9 to 1 , respectively. The collections of Braconid were made during nine months, with the glass collector removed each fifteen days giving thus two collections per month from September 2013 to May 2014. Nine traps were used in each orchard starting at $80 \mathrm{~m}$ from edge inside the orchard until 80 meters from the edge inside the forest. Traps were not installed in straight line to keep at least $60 \mathrm{~m}$ away from each trap (Figure 2). The specimens were identified in genus level based on identification keys proposed by Wharton et al..$^{22}$, Marsh ${ }^{23}$ using a stereomicroscope. The parasitoids analyzed were deposited at the Invertebrate Collection of the National Institute of Amazonian Research (INPA). 


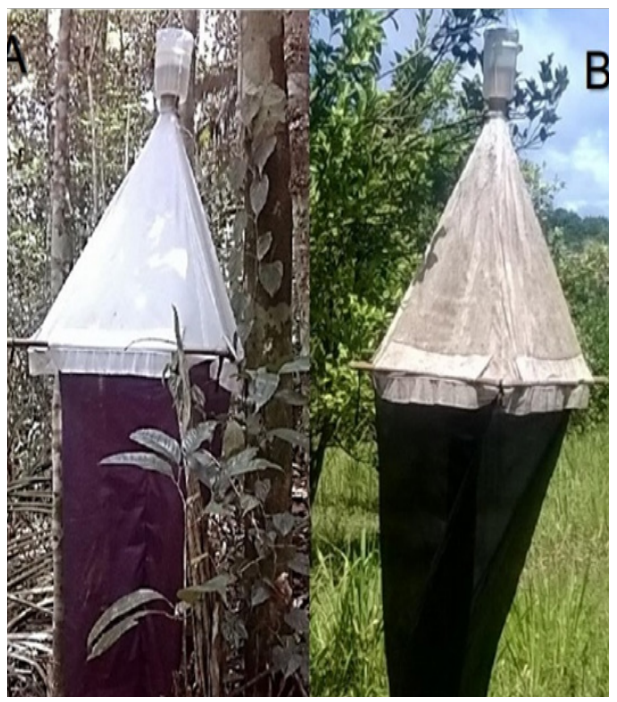

Figure I Modified Malaise traps.A) Inside the forest. B) Inside the orchard
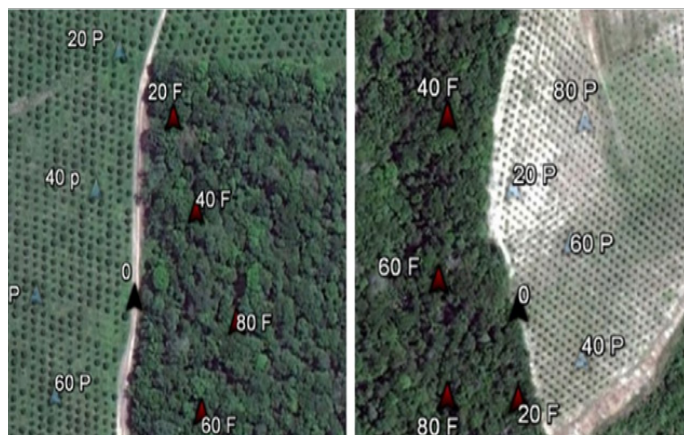

Figure 2 Disposition of Malaise traps inside A) Citrus orchard ApriscoPasárgada B)Citrus orchard Santa Terezinha. The numbers in front of the letters represents the distance in meters from the edge and the letters $(P)$ are the traps inside orchard and $(F)$ inside forest

For abundance data, the sums of all traps in each orchard and the sum of all traps in each secondary forest were used. The analysis of variance was done by adding all trapsper vegetation type (orchard or forest). The composition analysis was made using Principal Coordinates Analysis (PCoA) considering data of each trap inside each vegetation type. A posteriori test of analysis of variance was performed using the two first axes of the ordination provided by PCoA. Levels of significance were considered below 0.05.All analyses and graphics were run in the $\mathrm{R}$ version 2.1.1 environment for statistical computing, ${ }^{24}$ with Vegan and MASS packages.

\section{Results and discussion}

A total of 586 individuals were collected, distributed in 21 subfamilies and 65 genera. The four most abundant subfamilies were Doryctinae(176) Microgastrinae(109) Hormiinae(79) and Rogadinae(62) (Table 1). Abundance inside the forest, in the edge of forest and inside orchard were 315,77 and194 respectively. The edge abundance was different from forest and orchard and forest abundance was different from orchard (Figure 3). The most abundant families in forest were Doryctinae, Horminiae and Rogadinae and in orchard were Microgastrinae and Braconinae. The PCoA showed difference in the composition of forest and edge composition. Forest composition was similar to the edge (Figure 4). Moreover, exclusivity of some subfamilies in each vegetation type were found (Figure 5).

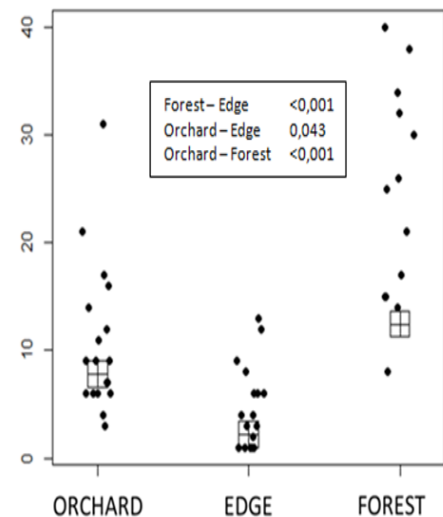

Figure 3 Abundance of Braconidae in orchards surrounded by secondary forest. *means p value below 0.05 .
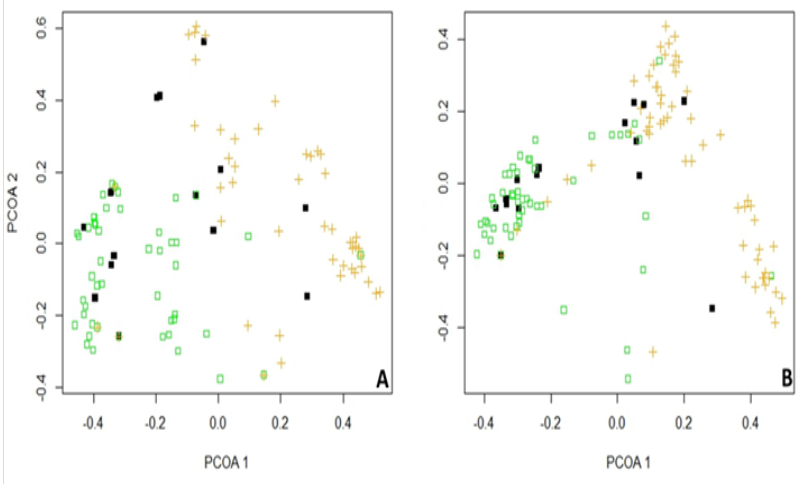

Figure 4 Principal coordinates analysis (PCoA) with data from both areas. A) Subfamily level. B) Genus level. (orange cross=orchard; black square=edge; green square $=$ forest).

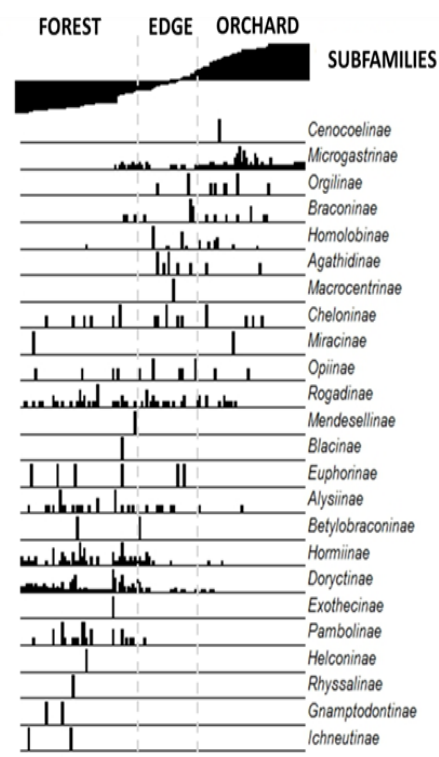

Figure 5 Distribution of subfamilies of Braconidae in the forest, edge and orchard. 
Table I Presence of the genus within the orchards

\begin{tabular}{|c|c|c|c|c|c|c|c|c|c|c|c|c|c|c|c|c|c|c|c|}
\hline \multirow{2}{*}{ Subfamily/Genus } & & \multicolumn{9}{|c|}{ Aprisco Pasárgada } & \multicolumn{9}{|c|}{ Santa Terezinha } \\
\hline & & $80 \mathrm{P}$ & $60 P$ & $40 P$ & $20 \mathrm{P}$ & Borda & $20 M$ & $40 M$ & $60 M$ & $80 M$ & $80 P$ & $60 \mathrm{P}$ & $40 P$ & $20 P$ & Borda & $20 M$ & $40 \mathrm{M}$ & $60 M$ & $80 M$ \\
\hline & Alabagrus & & & & $x$ & & & & & & & & & & & & & & \\
\hline \multicolumn{20}{|l|}{ Agathidinae } \\
\hline & Bassus & & $x$ & $x$ & & & & & & & & & $x$ & & & & & & \\
\hline & Aphaereta & & $x$ & & $x$ & $x$ & & $x$ & & $x$ & & & & & & & & & \\
\hline & Asobara & & & $x$ & & & & & & & & & & & & & & & \\
\hline \multicolumn{20}{|l|}{ Alysiinae } \\
\hline & Dinotrema & & & & & & $x$ & $x$ & $x$ & $x$ & & & & & $x$ & & $x$ & $x$ & $x$ \\
\hline & Phaenocarpa & & & & & & & & $x$ & $x$ & & & & & & & & & \\
\hline Betylobraconinae & Jannya* & & & & & & & & & $x$ & & & & & & & & $x$ & \\
\hline \multirow[t]{3}{*}{ Blacinae } & Dyscoletes* & & & & & & & & & & & & & & & & & & $x$ \\
\hline & Braconinae & & & & & & & & & & & & & & & & & & \\
\hline & Bracon & $x$ & $x$ & $x$ & & $x$ & & & & $x$ & & $x$ & & & & $x$ & & $x$ & \\
\hline \multicolumn{20}{|l|}{ Braconinae } \\
\hline & Hemibracon & $x$ & $x$ & & & & & & & & & & & & & & & & \\
\hline Brachistinae & Eubazus & & & & & & & & & & & & & & $x$ & & & & \\
\hline \multirow[t]{2}{*}{ Cenocoelinae } & Capitonius & $x$ & & & & & & & & & & & & & & & & & \\
\hline & Chelonus & & $x$ & $x$ & $x$ & & & & & & & $x$ & & & & & & $x$ & \\
\hline \multirow[t]{8}{*}{ Cheloninae } & Phanerotoma & & & & & $x$ & & & & & & & & & $x$ & & & & \\
\hline & Pseudophanerotoma & & & & & & & & $x$ & & & & & & $x$ & & & & $x$ \\
\hline & Barbalhoa & & & & & & & & & & & & & & & & & & $x$ \\
\hline & Ecphylus & $x$ & & & & & & & $x$ & $x$ & & & & & & $x$ & & & \\
\hline & New g. E & & & & & & & & & $x$ & & & & & & & & & \\
\hline & Heterospathius & & & & & & $x$ & $x$ & $x$ & $x$ & & & & & $x$ & & & & $x$ \\
\hline & Heterospilus & $x$ & $x$ & & $x$ & $x$ & $x$ & $x$ & $x$ & $x$ & & & & $x$ & $x$ & $x$ & $x$ & $x$ & $x$ \\
\hline & Johnsonius & & & & & & & & & & & & & & & & & $x$ & \\
\hline \multicolumn{20}{|l|}{ Doryctinae } \\
\hline & Leluthia & & & & & & & & & & & & & & & $x$ & & & \\
\hline & Leptodoryctes & & & & & & $x$ & & & & & & & & & $x$ & $x$ & & \\
\hline & Neoheterospilus & & & & & & & $x$ & $x$ & $x$ & & & & $x$ & & & & $x$ & $x$ \\
\hline & Notiospathius & & & & & & $x$ & $x$ & & $x$ & & & & & & $x$ & $x$ & $x$ & $x$ \\
\hline & Pioscelus & & & & & & & & & & & & & & $x$ & & & & \\
\hline & Stenocorse & & & $x$ & & & & & & & & & & & & & & & \\
\hline & Aridelus & & $x$ & & & & & & & & & & & & & & & & \\
\hline & Centistes & & & & & & & & $x$ & & & & & & & & & & \\
\hline \multicolumn{20}{|l|}{ Euphorinae } \\
\hline & Euphoriella & & & & & & & & & $x$ & & & & & & & $x$ & & \\
\hline & Plynops & & & & $x$ & & $x$ & & & & & & & & & & & & \\
\hline Exothecinae & Colastes & & & & & & & & & $x$ & & & & & & & & & \\
\hline & Gnamptodon & & & & & & & & & & & & & & & & & $x$ & \\
\hline \multicolumn{20}{|l|}{ Gnamptodontinae } \\
\hline & Pseudognaptodon & & & & & & & & & & & & & & & & $x$ & & \\
\hline Homolobinae & Exasticolus & $x$ & $x$ & $x$ & $x$ & $x$ & & & & & & & & & & & & & \\
\hline
\end{tabular}


Table Continued..

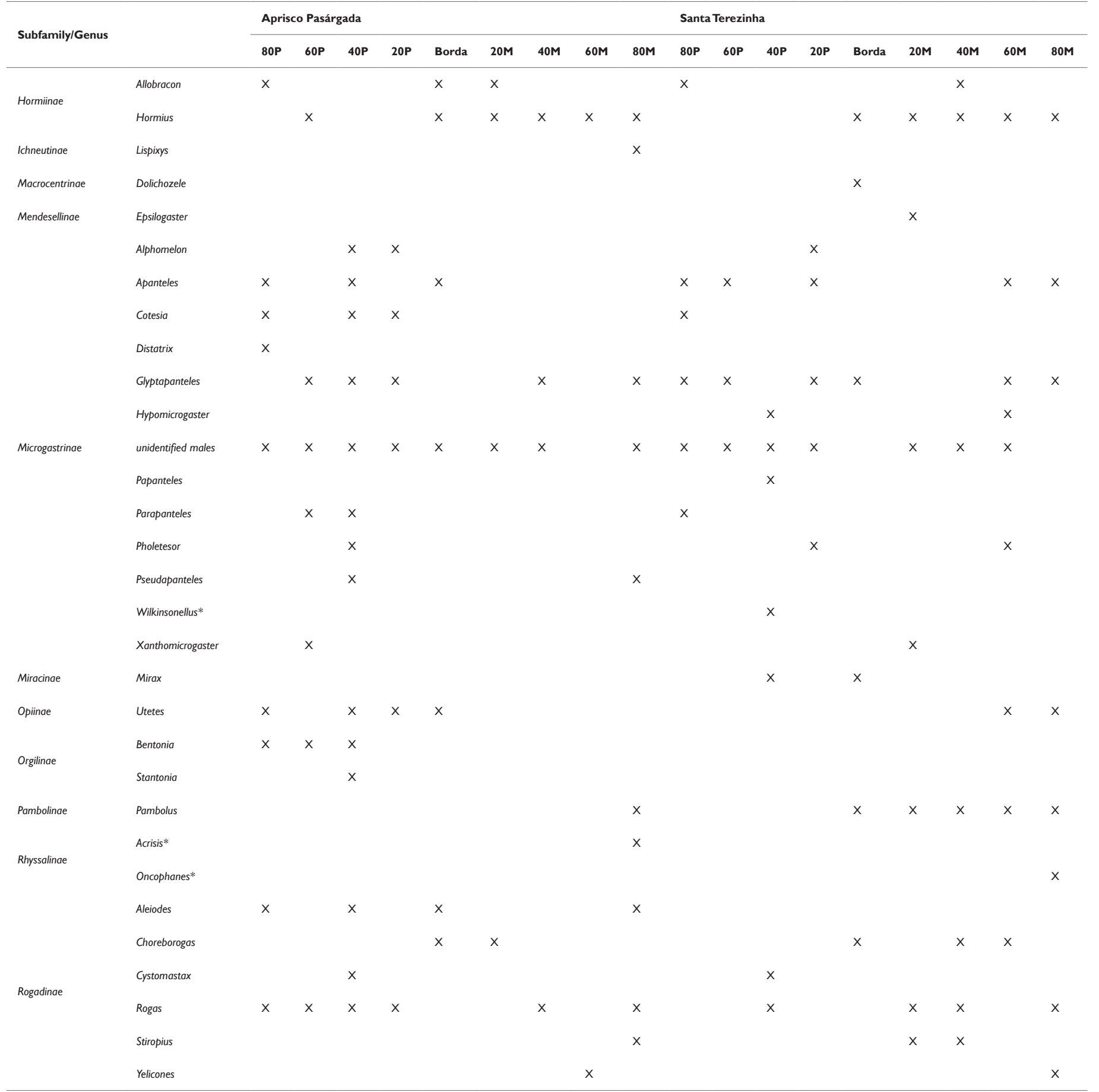

*New records for Brazil

Insect composition is influenced by several factors such as weather conditions, presence of hosts (in case of parasitoids), and presence of food and also by types of vegetation. Therefore, a monoculture plantation, as it happens in the Citrus orchards, can favor the presence of a limited group of phytophagous insectsin which consequently favors the presence of a specific niche of parasitoids. ${ }^{25-27}$ This was the case of groups like Microgastrinae, Orgilinae, Braconinae, Homolobinae and Agathidinae, which occurred mainly in the orchard. These groups are generally associated with parasitism of larvae of Lepidoptera. ${ }^{22,28}$ Even though wasn't made any quantitative survey of Lepidoptera larvae we were able to observe these individuals in the orchard during the sampling period. This may have contributed to the presence of the subfamilies cited. A more specific example is the genus Pholetesor Mason, 1981 (Microgastrinae) whose most specimens were collected in the orchard. This genus has been recorded by Santos et al. ${ }^{29}$ as parasitoid of Phyllocnistis Zeller, 1848, which is one of the main pests of citrus, and the species Phyllocnistis citrella Stainton, 1856, was present in the orchard.

Tropical rain forests have a greater diversity of plants and insects with a more bearable environment if compared to a Citrus orchard. This environment can create exclusivity of some groups that present 
some specificity of niches and habits of life, as Doryctinae that are mainly parasitoid of wood-boring beetles ${ }^{23}$ and attack larvae of beetles inside stems. The higher diversity of Doryctinae inside forest is explained by the high diversity of trees found inside forest in contrast with the low diversity inside orchard (only Citrus trees). Hormiinae and Pambolinae, as another example, were present almost exclusive in the forest. These subfamilies have the habit of parasitize insects that can hide some way inside plant tissue (leaf miners, gall or borers). ${ }^{30}$ Hormius Nees, 1819 (Hormiinae), for example, is parasitoid of Gelechiidae, Tortricidae and Coleophoridae all Lepidoptera ${ }^{30}$ which should certainly occur inside forest but not inside orchard, where the only leaf miner found was Phyllocnistis (Gracillariidae). Pambolus Haliday, 1836 (Pambolinae) is parasitoid of Coleoptera $^{30}$ which has been little observed in the orchard areas.

There are only few studies with ecological observations regarding the Braconidae fauna in the Amazonian region. In this study, the number of Braconidae specimens (586) were less than the approximately nine thousand collected by Feitosa et al. ${ }^{18}$ with three malaise traps (type: Gressit and Gressit, 1962) for a year, and less than almost three thousand collected by Querino et al. ${ }^{19}$ using twenty-four suspended traps for a year. Our numbers surpassed only Gadelha et al..$^{20}$ in which were collected 377 individuals using six malaise traps (type: Towns 1972) for a year. In addition, using 18 modified malaise traps for eight months we were able to record a higher number of subfamilies (21) and genera (65) than that showed by Gadelha et al. ${ }^{20}$ Furthermore, six subfamilies (Betylobraconinae, Blacinae, Euphorinae, Icneutinae, Mendesellinae and Miracinae) and 38 genera weren't recorded in any of the studies cited above. Were found some potential groups for biological control of citrus pests, mainly inside orchard, for instance, Utetes Forester (Opiinae). This genus uses fruitinfesting tephritids as its main host ${ }^{31}$ and despite this type of pest still not attack Citrus orchards in the northern region of Brazilits presence in the orchard is an indicative of a possible natural defense against tephritids, if it ever occurs.

\section{Conclusion}

The difference of Braconidae composition was caused by the presence of groups of agricultural importance on orchard and it can be attributed by the difference of vegetation between orchard and forest. Was collected some groups that are promising for biological control and if better studied it is possible to develop a regional biological control to reduce the use of pesticides. The distribution of some genera was expanded to Brazil, and those new records occurred mainly inside forest, showing the importance of maintain the forests and it should be taken in account a manner to keep most of the forest around orchard due to the diversity of genera that have been found.

\section{Acknowledgements}

The authors would like to thank the owners of the orchards studied, CAPES for the scholarship provided for the students, INPA for the infrastructure, EMBRAPA for the financial support in the collections and Dr. Marcos Vinícius Bastos Garcia.

\section{Conflict of interest}

Authors declare there is no conflict of interest in publishing the article.

\section{References}

1. IBGE. Brazilian Institute of Geography and Statistic. Brazil; 2009.

2. IBGE/CEPAGRO. Systematic Survey of Agricultural Production. 2014. p. 1-119.

3. Fernández F, Sharkey MJ. Introduction to the Hymenoptera of the Neotropical Region. National University of Colombia, Colombia; 2006. p. 1-894.

4. Yu D, Achterberg C, Horstmann K. Taxapad 2012, Ichneumonoidea 2011. Ottawa, Canada; 2012.

5. Wharton RA. Manual of the New World genera of the family Braconidae (Hymenoptera). In: Wharton RA, Marsh PM, editors. Special publication of the International Society of Hymenopterists. Washington, USA; 1997. p. 1-18.

6. Quicke DLJ. The Braconid and Ichneumonid Parasitoid Wasps: Biology, Systematics, Evolution and Ecology. Wiley-Blackwell, 2015. p. $1-704$.

7. Gravena S. Practical handbook on ecological management of citrus pests. Jaboticabal, Brazil; 2005. p. 1-372.

8. Parra JRP, de Oliveira Oliveira HN, de Sene Pinto A. Illustrated guide to beneficial citrus pests and insects. 2003. p. 1-140.

9. Efrom CFS, Botton M. Bioecology and control of fruit flies in citrus. Caxias do Sul: University of Caxias do Sul. Technical Booklet Citri culture. 2012. p. 1-5.

10. Daza NAC, Zucchi RA, Silva NM, et al. Recognition of the parasitoid species (Hym: Braconidae) of fruit flies (Dip: Tephritidae) in two municipalities of the State of Amazonas, Brazil. Bulletin of the Museum of Entomology of the Universidad del Valle. 1994;2:1-7.

11. Silva WR, Silva RA. Survey of fruit flies and their parasitoids in the municipality of Ferreira Gomes, State of Amapá. Rural Science. 2007;37(1):265-268.

12. Jesus CR, Pereira JDB, Oliveira MN, et al. New Records of Fruit Flies (Diptera: Tephritidae), Wild Hosts and Parasitoids (Hymenoptera: Braconidae) in the Brazilian Amazon. Neotropical Entomology. 2008;37(6):733-734.

13. Costa SGM, Querino RB, Ronchi-Teles B, et al. Parasitoid diversity (Hymenoptera: Braconidae and Figitidae) on frugivorous larvae (Diptera: Tephritidae and Lonchaeidae) at Adolpho Ducke Forest Reserve, Central Amazon Region, Manaus, Brazil. Brasilian Journal of Biology. 2009;69(2):363-370.

14. Thomazini MJ, Albuquerque ES. Parasitoids (Hymenoptera: Braconidae) of Anastrepha Schiner (Diptera: Tephritidae) in the state of Acre, Brazil. Acta Amazonica. 2009;39(1):245-248.

15. Pereira JDB, Buriti DP, Lemos WP, et al. Species of Anastrepha Schiner (Diptera: Tephritidae), its hosts and parasitoids in the States of Acre and Rondônia, Brazil. Biota Neotropica. 2010;10:441-446.

16. Silva RA, Lima AL, Xavier SLO, et al. Anastrephaspecies (Diptera: Tephritidae), their hosts andparasitoids in southern Amapá State, Brazil. Biota Neotropica; 2011;11(3):431-436.

17. Zucchi RA, Marinho CF, Silva RA. First Record of the Fruit Fly Parasitoid Doryctobracon crawfordi (Viereck) (Hymenoptera: Braconidae) in Brazil. Neotropical Entomology. 2011;40(6):711-712.

18. Feitosa MCB, Querino RB, Henriques AL. Profile of the fauna of parasitoid wasps (Insecta: Hymenoptera) in forest reserve in Amazonia, Amazonas, Brazil. Entomotropica. 2007;22(1):37-43. 
19. Querino RB, Couceiro SEM, Queiroz LO, et al. The spatial distribution of Hymenoptera parasitoids in a forest reserve in Central Amazônia, Manaus, AM, Brazil. Brazilian Journal of Biology. 2011;71(4):865-871

20. Gadelha SS, Penteado-Dias AM, Silva ADA. Diversity of Braconidae (Insecta, Hymenoptera) of the Parque Natural Municipal de Porto Velho, Rondonia, Brazil. Revista Brasileira de Entomologia. 2012;56(4):468-472.

21. Townes H. A light-weight Malaisetrap. Entomological news. 1972;83:239-247.

22. Wharton RA, Marsh PM, Sharkey MJ. Manual of the New World genera of the family Braconidae (Hymenoptera). Special publication of the International Society of Hymenopterists. Washington, USA; 1997. p. $1-439$.

23. Marsh PM. The Doryctinae of Costa Rica (excluding the genus Heterospilus). Memoirs of The American Entomological Institute. 2002;70:1319.

24. R Development Core Team. R: A language and environment for statistical computing. R Foundation for Statistical Computing, Vienna, Austria; 2011.

25. Cook-Patton SC, LaForgia M, Parker JD. Positive interactions between herbivores and plant diversity. Proc Biol Sci. 2014;281(1713):20140261.
26. Plath M, Mody K, Potvin C, et al. Establishment of native tropical timber trees in monoculture and mixed-species plantations: small-scale effects on tree performance and insect herbivory. Forest ecology and management. 2011;261(3):741-750.

27. Risch SJ. Insect herbivore abundance in tropical monocultures and polycultures: an experimental test of two hypotheses. Ecology. 1981;62(5):1325-1340.

28. Shaw MR, Huddleston T. Classification and biology of braconid wasps. Handbooks for the identification of British insects. 1991;7:1-126.

29. Santos JP, Soglio FKD, Redaelli LR, et al. Parasitoids of Lepidoptera miners present in plants of spontaneous growth in organic orchard of citrus in Montenegro-RS. Brazilian Journal of Fruticulture. 2007;29(1):80-84.

30. Whitfield JB, Wharton RA. Subfamily Hormiinae. In: Wharton RA, Marsh PM, editors. Manual of the New World genera of the family Braconidae (Hymenoptera). Special publication of the International Society of Hymenopterists, Washington, USA; 1997. p. 285-301.

31. Wharton RA. Subfamily Opiinae. In: Wharton RA, Marsh PM, editors. Manual of the New World genera of the family Braconidae (Hymenoptera). Special publication of the International Society of Hymenopterists, Washington, USA; 1997. p. 379-395. 